\title{
The Relationship between Voting Behavior and Election Commitment: A Literature Review
}

\author{
Qin Guo \\ School of Administrative Management, Jinan University, Guangzhou, China \\ Email:gq2017jnu@163.com
}

How to cite this paper: Guo, Q. (2020). The Relationship between Voting Behavior and Election Commitment: A Literature Review. Open Journal of Social Sciences, 8 , 201-210.

https://doi.org/10.4236/jss.2020.82016

Received: January 30, 2020

Accepted: February 25, 2020

Published: February 28, 2020

Copyright $\odot 2020$ by author(s) and Scientific Research Publishing Inc. This work is licensed under the Creative Commons Attribution International License (CC BY 4.0).

http://creativecommons.org/licenses/by/4.0/ (c) (i) Open Access

\begin{abstract}
By reading the existing literature and combining the Chinese reality, based on a literature review of the research results on the relationship between election commitments and election behaviors, this paper summarizes the existing academic achievements and finds that academic discussion on the relationship between election behavior and election commitment forms three perspectives: just a cheap talk view, determining view and neutral view.
\end{abstract}

\section{Keywords}

Voting Behavior, Election Commitment, Selection

\section{Introduction}

"Building the No. 1 Village on the Bank of the Yellow River!" This inspiring slogan comes from the 2009 election of the director of the village committee of Gaojie Village, Qingjing County, Shaanxi Province. A 19-year-old girl named Bai Yitong from northern Shaanxi, delivered a keynote speech entitled "Building the No. 1 Village on the Bank of the Yellow River" and made "Top Ten Promises": build a comprehensive service building, build a Western House, repair a theater, repair a road, solve draught problems, etc. In the end, Bai Yitong was elected as the village director and was hailed as "Chinese Countryside Obama" in Mainland China. On December 28, 2011, Gaojie Village held a village committee for general elections, and she was re-elected as the director of Gaojie Village Committee. It is noteworthy that Bai Yitong received 244 votes out of 338 votes, and the support rate dropped from $97.6 \% 3$ years ago to $72 \%$. And the reduction of the support rate is "blessed" to a certain extent the fulfillment of these ten promises. Regarding the relationship between election commitments and voting behavior, Corazzini et al. (2014) found that without a motive for re-election, the 
level of commitment fulfillment was about $60 \%$. Born et al. (2017) further pointed out in the research that election commitments will affect voting behavior and voters' beliefs (credibility), and their relationship is in an inverted $\mathrm{U}$-shape, that is, election commitments are usually credible, unless especially high. This article hopes to use this phenomenon in our country, based on a comprehensive analysis of existing foreign literature, to explore whether there is an inverted U-shaped relationship between voting behavior and election promises in China, and to what extent are promises fulfilled.

The research on the voting behavior of voters can be traced back to the 1950s. Towns analyzed the behavior logic of voters and politicians based on the hypothesis of rational economic man. In 1960, Angus Campbell successively proposed the influence of "identification, attitudes, social groupings, candidate evaluation, and issue selection" on voter voting behavior. On this basis, scholars mainly focus on "party identification, candidate evaluation and issues" and other influencing factors of election behavior, and have produced fruitful research results. However, there are still few studies on the relationship between voting behavior and election commitment. As an indispensable part of the campaign, election promise not only involves the future policy direction, but also affects the expectation deviation of voters. Based on the existing literature, the academic circles have formed the following opinions on whether and how election promises affect the voting behavior of voters.

\section{A Cheap Talk}

The public often believes that politicians rarely honour their election promises during the campaign, and that these promises are also unreliable (Barro, 1973; Julia, 2019). Scholars have conducted extensive research on election promises, cheap talks. Scholars who hold this view believe that election promises are simply cheap talks made by candidates in order to win votes, so election promises will not affect the public's voting behavior and provide no information for voters to make decisions (Barro, 1973). Barro (1973) applied economic theory and analysis of the public sector to point out that there is a division of interests between the public and their political representatives, and this benefit division is precisely because public officials act only for their own interests. Does not align with the interests of voters. There is therefore no necessary link between election commitments and voter behavior.

This statement has also been verified by other scholars. As mentioned in the static environment model constructed by McKelvey (1975), few people notice the possibility that once a candidate is elected, the preferences of politicians may differ from those of voters. On this basis, Ferejohn (1986) pointed out that in the pure theory of electoral competition, a citizen would compare the candidate's parties, and then vote for the candidate he supports according to personal preference. In this regard, Krasa, S., \& Polborn, M. K. (2015) also pointed out that in addition to the policy positions of the candidates, the influence of the party affil- 
iation of the candidates on the voters is also very important, and in an equilibrium state, the party candidates may not be able to escape the burden of the party alliance. But it should be pointed out that there is a difference between the political party competition in China. Then, Ferejohn (1986) pointed out that people have not considered whether such a "preference fit" is in line with civil servants. The benefit is simply assuming that promises will be fulfilled and citizen preferences will be responded to by policies. But in reality, candidates make commitments or make policies based on their personal or partisan interests. So, what can lead to voters' voting behavior since the candidate's political party, rather than election commitments, is the trigger mechanism for voting behavior? Some scholars have pointed out that if voters are uncertain about the characteristics of the incumbent, rational citizens will often evaluate candidates based on their past performance (performance) results (Besley \& Case, 1995). This voting behavior is called "backdating" voting by academia. A recent study also critiques the existing literature's hypothesis that voters prefer political parties to fulfill their campaign promises, while voter-supported parties are more inclined to keep their promises (Werner, 2019). Werner (2019) doubts whether voters agree with this hypothesis, and uses Australia as a background to explore voters' preferences for three ideal party representation styles: trustworthiness, attention to public opinion, and the pursuit of common interests. It also tests whether voters prefer their party over others to keep their promises. In the end, he pointed out that among the three ideal representation styles, what voters do not care about most is whether the party keeps its promises, and their preferences will not be affected by the support of the party. Challenging the omnipresent party effect.

How does retrospective voting affect candidates? Besley \& Case (1995) empirically verified that the retrospective voting (democracy accountability) has a binding effect on politicians, and provides effective support for the retrospective voting to restrain the behavior of politicians. He pointed out that voters will punish politicians in repeated elections (re-election?), And officials who intend to run for public office again must always act in the interests of voters in order to win re-election. Although models based on this idea are becoming more and more popular in formal principal-agent literature, their practical significance is rarely known. On this basis, Woon (2012) once again experimentally explored the concerns of voters-whether to focus on election choices or election sanctions. He criticized forward-looking voting and stated that "if you are not sure about the characteristics of politicians and look forward, then this voting choice is rational. But doing so undermines democratic accountability because choice makes approval a void Threat. "In contrast to rational choice predictions, his research further states Voters have a strong tendency to act on retrospective voting rules, and can have a restrictive effect on the behavior of politicians, providing support for voters' more inclined to accountability (retrospective voting). At the same time, we need to see that the restrictive effectiveness of retrospective voting (administrative accountability) on politicians will be affected by other factors. 
Wolfers (2002) points out that voters are not rational and they make attribution errors. His research explores that in addition to signals, the response to noise information also weakens the link between politician behavior and elections, which in turn weakens political accountability and the power of voters to exercise incentives.

\section{Deterministic Relationship}

Although some scholars argue that the relationship between election behavior and election promises is a cheap promise, there are another view is that election promises are a prerequisite for voting and that politicians will keep their promises. Voters don't see promise as cheap talk, they will vote for candidates who promise more. However, this relationship is non-linear, as voters believe that an extremely generous campaign commitment is incredible (Corazzini et al., 2014). Election commitments, which appear in both the party's electoral programme and political declaration, are crucial to many variants of democracy. In particular, ensuring a close connection between election commitments and the actions of elected officials is a manifestation of good democratic functioning (Mansergh \& Thomson, 2007). Scholars holding this view mainly believe that voters' voting behavior depends on the party's election commitments, and by predicting the future political performance of the party after taking office, and then judging the future benefits of individuals, then decide whether to vote. It can be seen that the voting behavior of voters is predicted based on the "future", and the academic community calls this "future expectation" voting "prospective voting". As early as Downs (1957) modeled the behavioral logic of voters and politicians based on the hypothesis of rational economic people in his "Economic Theory of Democracy", arguing that "cost-benefit" determines whether voters vote Consider it at all. Voters will compare candidates 'policy positions and commitments, Make a judgment on the future performance of the party after taking office, form his own voting decision, and vote for him who believes that in the future term he will bring him higher utility income (utility flow) than any other party Political parties (Downs 1957). According to the existing research, the existing research on this kind of decision/influence relationship can be summarized into the following dimensions.

\subsection{Consistency of Commitment Preferences and Public Preferences}

Consistency of commitment preferences and public preferences. Scholars point out that politicians make election commitments and make policies based on voters' preferences, and voters also vote based on commitments. In the Downs model, since the political party's policy-making is made after taking office, the political platform of the opposition party is also based on the policies made by the ruling party. Therefore, he pointed out that voters' voting decisions are based only on their election commitment And consider voters to be motivated by vot- 
ing commitments that are consistent with their policy preferences. But will the promises of politicians really match the preferences of voters? Downs pointed out that in order to obtain votes, politicians' commitments will be in line with middlemen to a certain extent. Political parties make policies to win elections, not to make policies to win elections. To some extent, in order to compete for votes, politicians must align with the majority of voters, formulate or implement policies that reflect the wishes of the majority, and then move politicians closer to the middle. Under the two-party system, each party has intentionally made ambiguous promises (Downs 1957; Lee \& Butler, 2004). In this case, the current party. The difference is equal to 0 . Voters compare the performance of the ruling party with its ideal (the performance of the previous ruling party) to form a realistic and ideal assessment. Therefore, the above argument shows that politicians and the public will be consistent in election commitments and public preferences. Grossback et al. (2005) further analyzed the different authorization models and pointed out that the public-driven model indicates that Congress plays different roles. Instead of surrendering to a weak president, Congress reflects what it sees as a voter preference and responds to public policy preferences. Because rational citizens vote for a party that supports their own positions. Discussion above suggests that a more traditional politicians behavior patterns, under this prediction, politicians would choose the more moderate position. But some scholars believe that promises are not It must be consistent with public preferences. Alesina, A. (1988) points out, in fact, it is difficult to establish a credible commitment and it is an important reality in the world by the empirical research on the voting behavior of the U.S. House of Representatives (1946-1994). Lee \& Butler (2004) pointed out that voters only choose the behavioral logic of their policies during the election. However, the size of the election forces will not affect the policy direction of politicians, and politicians cannot convincingly promise a compromise. Its research on politician commitment and public preference Compromise and consistency pose challenges.

Based on the above analysis of existing literature, it can first be clarified that there is a mutual influence relationship between election behavior and election commitment, whose relationship is affected by the consistency of preference. The next section explores how, in addition to the consistency of preferences, the extent to which politicians deliver on promises also affects electoral behaviour. These two parts analyze the influencing factors of the relationship between election behavior and election commitment.

\subsection{Will Politicians Really Keep Their Promises?}

Although studies have shown that citizens often believe that politicians will not keep their promises, recent studies on promise fulfillment have shown that, in general, most legitimate election commitments are consistent with post-election policy output (Julia, 2019). Corazzini et al. (2014) found that in the absence of re-election motivation, the level of commitment fulfillment was about $60 \%$. It 
noted that electoral competition prompted candidates to make more generous campaign promises, and that those promises were partially fulfilled. Thomson et al. (2017) states that political parties have not fully adjusted their commitments to the political and economic constraints they face in government. If the parties do respond accurately to these expectations, they will make a more modest commitment when they want to join the alliance or the economy is weak, so that the possibility of fulfilling the promise is the same regardless of these conditions. Studies by scholars such as Julia (2019) have also shown that ruling parties have actually fulfilled most of their commitments before the election, and the public believes that their failure to keep their commitments is likely to be related to the public's definition of election commitments. Whether or not we fulfill our promises depends more on the public's understanding of election promises and satisfaction with the ruling party.

\subsection{Impact of Compliance with Election Commitments on Voters' Voting Behavior}

Previous research has shown that election commitments have an impact on voters' voting behavior (Towns, 2010; Austen-Smith \& Banks, 1999; Johnson \& Ryu, 2010; Corazzini et al., 2014). Towns initially pointed out that the political party's election commitments will be the basis for judging voters' voting behavior. As the ruling party, in order to improve the government's chance of winning in the next election, they also have the motivation to formulate the policies it supports in the last election because Voters evaluate it not only in accordance with its current policies but also in the implementation of its previous election commitments. Therefore, the establishment and implementation of election commitments is particularly important if you want to continue to be re-elected. Austin smith \& banks (1989) further validated the importance of complying with election promises during reelection, noting that the re-election of voters to the current president depends on the current president's adherence to his campaign agenda. Johnson \& Ryu (2010) research shows that breach of commitment will exacerbate the consequences of poor economic performance, amplify the benefits of good economic performance, and then affect voter voting behavior. Corazzini et al. (2014) also showed that although politicians "compliance with their commitments was partially fulfilled, he also proved that election commitments can affect voters" voting behavior. In addition, some scholars have pointed out that the use of the media will also affect voters' forward-looking evaluation of candidates. Kartik \& Mcafee (2007) shows that political parties will use election platforms to communicate and make promises to voters by constructing a one-dimensional election competition model, and voters will judge candidates based on platform information. However, the use of this platform will also generate certain externalities, causing a signaling game between candidates and voters to affect voter effectiveness and voting behavior. 


\section{Neutral View}

In fact, the relationship between election promises and election behavior is not linear. Is retrospective voting and forward-looking voting necessary? Eclectic scholars believe that voters may take into account politicians' early performance and commitments and adopt different strategies when voting. Mackuen \& Stimson (1992) distinguishes between types of voters, noting that some voters will incorporate new information about the future into their personal economic expectations when making their voting choices, and they call such voters "banks Home, "and refer to voters in the" retrospective "voting style as" farmers, "meaning that their expectations are based solely on recent economic performance or personal economic experience, not long-term planning. Corazzini et al. (2014) find that when candidates were free of conflicts of interest and reputational concerns, they kept promises about 60 percent of the time on average, and their research shows that voters fare just as badly when candidates are not allowed to make any promises as when they are not. As a result, studies show that not only is electoral competition important, so is pre-election commitment. As a response to Corazzini et al. (2014) Complementing and responding to the research, Born et al. (2017) proposed that neither pessimism nor optimism about election commitments is completely correct, but the fact is in the middle of the two. He introduced voters' beliefs (credibility) in election commitments, and made improvements to previous research. He specifically distinguished between forward-looking voting and retrospective voting, and defined that purely forward-looking voting would not punish disciplinary mistrust. The behaviors of those who have formed their lives can only form expectations of their future behaviors with the promises and past behaviors of the incumbents, while retrospective voters will punish politicians who violate their promises. In the end, he proposed that election commitments affect voting behavior and the beliefs (credibility) of voters, and that their relationship is U-shaped, that is, election commitments are usually credible unless they are particularly high. If re-elections are possible, and if politicians come to power by voting instead of random draws, politicians will commit more frequently. This further complements the point that Corazzini et al. (2014)'s election is better than appointments. Final research shows that voters will actually rely more on the forward-looking model when they vote beforehand, and punish politicians for breaking promises after the fact.

Regardless of voters' preferences, voting is really a choice among many alternatives (Ginsberg, 1976). This choice as whether consumers fully aware of the differences between the products, his behavior has a crucial influence to the national economy, in the same way, regardless of whether voters completely realize the impact of their behavior, brings with it a corresponding policy consequences, which affect the supply of public goods, or cause a series of series of voting with their feet, etc. Therefore, the research on voting behavior not only involves the democratic process of national governance, but also affects the broader field of 
public administration. Since the public choice theory to apply the principle of economics, political science about the election process and voting thering is no lack of research on the trading rules of the minority, but the deeper research is based on more democratic electoral system has perfect representative democracy, the election campaign in these countries mostly just need to provide a good policy and rules in order to achieve good operation, combining our country's primary election, probably in a lot of behind the "election" prosperity, there are still mysteries of downs and participation, therefore, we also need to be based on the specific Chinese election to explore whether the election promises to voting behavior in our country will also constitute a significant impact.

\section{Conclusion}

To sum up, from the past research, the research on the relationship between electoral behavior started earlier, but the research on the relationship between election commitment and voting behavior has only gradually increased in recent years. Taken together, there are roughly three perspectives on voters' voting behavior and election commitments. The first perspective tends to consider that election commitments and voting behaviors are irrelevant, and election commitments are merely cheap talk. Another view is that election commitment is the basis for voters to vote, that is, in prior elections, voters vote based on observations of politician commitments. The third perspective takes into account the first two perspectives, and considers that voters will consider both their early performance (performance) and election commitments when they vote. Therefore, in fact, retrospective voting and forward-looking voting do not necessarily exist in opposition. It is worth noting that in the retrospective voting model, politicians' "worries about re-election will not prevent them from making policy decisions based on their own preferences after taking office, and the forward-looking research voting model also ignores voters" expectations and the third mode is a compromise between the first two modes, which supplements the deviation between actual policies. However, it can be seen that, in addition to political commitment, some scholars have pointed out that the current level of economic development and the level of economic development of individual citizens will also affect voting behavior, and scholars rarely take this important factor into consideration when measuring the relationship between the two. At the same time, with the generation and use of new media, the academic community has not further discussed the impact of his commitment on elections and voting behavior, and the extent to which the passing effect of new media on commitments will affect voting behavior. It is worth our in-depth consideration.

However, the research on the relationship between election commitments and voting behavior is still in its infancy in China. This paper hopes to explain the behavior of grassroots elections in China by reading relevant foreign literature and explore the role of election commitments in grassroots elections in China. What is the compliance situation and whether the relationship between it and 
the election behavior is also inverted U-shaped, and then find a good way to promote grassroots autonomy.

\section{Conflicts of Interest}

The author declares no conflicts of interest regarding the publication of this paper.

\section{References}

Alesina, A. F. (1998). Credibility and Policy Convergence in a Two-Party System with Rational Voters. American Economic Review, 78, 796-805.

Austen-Smith, D., \& Banks, J. (1999). Electoral Accountability and Incumbency. In P. Ordeshook (Ed.), Models of Strategic Choice in Politics (pp. 121-148). Ann Arbor, MI: University of Michigan Press.

Barro, R J. (1973). The Control of Politicians: An Economic Model. Public Choice, 14, 19-42. https://doi.org/10.1007/BF01718440

Besley, T., \& Case, A. (1995). Does Electoral Accountability Affect Economic Policy Choices? Evidence from Gubernatorial Term Limits. Quarterly Journal of Economics, 110, 769-798. https://doi.org/10.2307/2946699

Born, A., Van Eck, P., \& Johannesson, M. (2017). An Experimental Investigation of Election Promises. Political Psychology, 39, 685-705. https://doi.org/10.1111/pops.12429

Corazzini, L., Kube, S., Marechal, M. A., \& Nicol, A. (2014). Elections and Deceptions: An Experimental Study on the Behavioral Effects of Democracy. American Journal of Political Science, 58, 579-592. https://doi.org/10.1111/ajps.12078

Downs, A. (1957). An Economic Theory of Political Action in a Democracy. Journal of Political Economy, 65, 135-150. https://doi.org/10.1086/257897

Duponta, J. C., Bytzekb, E., Steffensa, M. C., \& Schneiderc, F. M. (2019). Which Kind of Political Campaign Messages Do People Perceive as Election Pledges? Electoral Studies, 57, 121-130. https://doi.org/10.1016/j.electstud.2018.11.005

Ferejohn, J. (1986). Incumbent Performance and Electoral Control. Public Choice, 50, 5-25. https://doi.org/10.1007/BF00124924

Ginsberg, B. (1976). Elections and Public Policy. American Political Science Review, 70, 41-49. https://doi.org/10.1017/S0003055400263971

Grossback, L. J., Peterson, D. A. M., \& Stimson, J. A. (2005). Comparing Competing Theories on the Causes of Mandate Perceptions. American Journal of Political Science, 49, 406-419. https://doi.org/10.1111/j.0092-5853.2005.00131.x

Johnson, G. B., \& Ryu, S. R. (2010). Repudiating or Rewarding Neoliberalism? How Broken Campaign Promises Condition Economic Voting in Latin America. Latin American Politics \& Society, 52, 1-24. https://doi.org/10.1111/j.1548-2456.2010.00096.x

Kartik, N., \& Mcafee, R. P. (2007). Signaling Character in Electoral Competition. American Economic Review, 97, 852-870. https://doi.org/10.1257/aer.97.3.852

Krasa, S., \& Polborn, M. K. (2015). Political Competition in Legislative Elections (pp. 222-232). Champaign, IL: University of Illinois, Urbana-Champaign (VI).

Lee, D. S., \& Butler, M. M. J. (2004). Do Voters Affect or Elect Policies? Evidence from the U. S. House. The Quarterly Journal of Economics, 119, 807-859.

https://doi.org/10.1162/0033553041502153

Mackuen, M. B., \& Stimson, E. J. A. (1992). Peasants or Bankers? The American Electo- 
rate and the U.S. Economy. The American Political Science Review, 86, 597-611. https://doi.org/10.2307/1964124

Mansergh, L., \& Thomson, R. (2007). Election Pledges, Party Competition, and Policy Making. Comparative Politics, 39, 311-329.

McKelvey, R. D. (1975). Policy Related Voting and Electoral Equilibrium. Econometrica, 43, 815-843. https://doi.org/10.2307/1911327

Thomson, R., Royed, T., Naurin, E. et al. (2017). The Fulfillment of Parties' Election Pledges: A Comparative Study on the Impact of Power Sharing. American Journal of Political Science, 61, 527-542. https://doi.org/10.1111/ajps.12313

Towns, A., Translated by Yao Yang et al. (2010). Economic Theory of Democracy. Shanghai: Shanghai Century Press.

Werner, A. (2019). What Voters Want from Their Parties: Testing the Promise-Keeping Assumption. Electoral Studies, 57, 186-195. https://doi.org/10.1016/j.electstud.2018.12.006

Wolfers, J. (2002). Are Voters Rational? Evidence from Gubernatorial Elections. Rochester, NY: Social Science Electronic Publishing. https://doi.org/10.2139/ssrn.305740

Woon, J. (2012). Democratic Accountability and Retrospective Voting: A Laboratory Experiment. American Journal of Political Science, 56, 913-930.

https://doi.org/10.1111/j.1540-5907.2012.00594.x 